\title{
Synthesis and Biological Evaluation of Amidinourea Derivatives against Herpes Simplex Viruses
}

\author{
Anita Toscani ${ }^{1}$, Rossana Denaro ${ }^{1}{ }^{(D}$, Sergio Fernando Castillo Pacheco ${ }^{2}{ }^{(}$, Matteo Biolatti ${ }^{2}\left(\mathbb{D}\right.$, Silvia Anselmi ${ }^{1}$, \\ Valentina Dell'Oste ${ }^{2, *}$ a and Daniele Castagnolo ${ }^{1, *}$ (])
}

1 School of Cancer and Pharmaceutical Sciences, King's College London, London WC2R 2LS, UK; anita.1.toscani@kcl.ac.uk (A.T.); roxdenaro@gmail.com (R.D.); silvia.anselmi@kcl.ac.uk (S.A.)

2 Department of Public Health and Pediatric Sciences, University of Turin, 10124 Turin, Italy; sergiofernando.castillopacheco@unito.it (S.F.C.P.); matteo.biolatti@unito.it (M.B.)

* Correspondence: valentina.delloste@unito.it (V.D.); daniele.castagnolo@kcl.ac.uk (D.C.)

Citation: Toscani, A.; Denaro, R.; Pacheco, S.F.C.; Biolatti, M.; Anselmi, S.; Dell'Oste, V.; Castagnolo, D. Synthesis and Biological Evaluation of Amidinourea Derivatives against Herpes Simplex Viruses. Molecules 2021, 26, 4927. https://doi.org/ $10.3390 /$ molecules 26164927

Academic Editor: Athina Geronikaki

Received: 13 July 2021

Accepted: 12 August 2021

Published: 14 August 2021

Publisher's Note: MDPI stays neutral with regard to jurisdictional claims in published maps and institutional affiliations.

Copyright: (c) 2021 by the authors. Licensee MDPI, Basel, Switzerland. This article is an open access article distributed under the terms and conditions of the Creative Commons Attribution (CC BY) license (https:// creativecommons.org/licenses/by/ $4.0 /)$.

\begin{abstract}
Current therapy against herpes simplex viruses (HSV) relies on the use of a few nucleoside antivirals such as acyclovir, famciclovir and valacyclovir. However, the current drugs are ineffective against latent and drug-resistant HSV infections. A series of amidinourea compounds, designed as analogues of the antiviral drug moroxydine, has been synthesized and evaluated as potential non-nucleoside anti-HSV agents. Three compounds showed micromolar activity against HSV-1 and low cytotoxicity, turning to be promising candidates for future optimization. Preliminary mode of action studies revealed that the new compounds act in an early stage of the HSV replication cycle, just after the viral attachment and the entry phase of the infection.
\end{abstract}

Keywords: amidinourea; herpes simplex virus; guanidine; antivirals; amidines

\section{Introduction}

Herpes simplex viruses type 1 (HSV-1) and type 2 (HSV-2) are double-stranded (ds) DNA, nuclear-replicating and enveloped viruses, members of the Alphaherpesvirinae subfamily. They are associated with a number of clinical manifestations in humans, including cold sores, keratitis, meningitis and encephalitis as well as various other diseases in immunocompromised patients [1-3]. They are considered to be the most common pathogens affecting humans, as it has been calculated that $50-90 \%$ of the worldwide population is seropositive to HSV-1 [4,5]. One of the main problems with HSV is the ability of the viruses to become latent in sensory neurons and reactivate periodically, causing lesions at the original site of the primary infection, for instance, in the mouth or on the genitals [6]. It has been estimated than nearly 490 million people between 15 and 49 years of age live with an infection of HSV-2, which is the main cause of genital herpes [7]. HSV prevalence has been increasing in the last 20 years worldwide $[8,9]$ and HSV latent infections can cause lifelong major health problems to the host. The viral DNA can stay latent in the nucleus of sensory neurons and avoid the host's immune system, leading, in the long term, to life-threatening diseases such as neurological disorders, encephalitis and blindness [8,9]. Recently, a link between the infections of HSV-1 and neurodegenerative diseases such as Alzheimer's disease has been demonstrated [10-12]. The standard therapy against HSV infections relies on the use of the antiviral acyclovir and related nucleoside analogues, such as famciclovir and valacyclovir (Figure 1), while no effective vaccine is currently available $[13,14]$. Although acyclovir is effective against primary infections, it proved to be ineffective against the latent virus and thus unable to completely eradicate the infection from the host. In addition, the nephrotoxicity associated with acyclovir and the emergence of drug-resistant HSV strains [15-17] highlights the need to identify new anti-HSV drugs, possibly working with a different mode of action. Amidinoureas are a class of organic compounds that find application in medicinal chemistry as antifungal, antibacterial and 
anticancer agents [18-23]. Recently, our group reported the synthesis of a series of amidinourea derivatives, designed as analogues of the antiviral drug moroxydine, an inhibitor of hepatitis C virus (HCV) [24,25]. These molecules seem to act against HCV virus through a mode of action that differs from that of nucleoside-based antivirals, namely the inhibition of virus translation.<smiles>Nc1nc(=O)c2ncn(CCOC(=O)O)c2[nH]1</smiles><smiles>CC(=O)OCC(CCn1cnc2cnc(N)nc21)COC(C)=O</smiles><smiles>CC(C)C(N)C(=O)OCCOCn1cnc2c(=O)nc(N)[nH]c21</smiles><smiles>COCCNC(=N)NC(=N)N</smiles><smiles>[R]NC(=N)NC(=O)N1CCCCC1</smiles>

Figure 1. Antivirals active against HSV and the general structure of the amidinourea antivirals discussed in this work.

Driven by our interest on amidinoureas and antimicrobial agents, we decided to further investigate the antiviral properties of amidinourea analogues of moroxydine against DNA viruses. Herein, we describe the synthesis of a series of amidinourea derivatives, designed as isosters of moroxydine, having the general structure reported in Figure 1 and their evaluation against HSV-1 and HSV-2.

\section{Results and Discussion}

A library of amindinourea compounds was synthesized as shown in Scheme 1 [24].

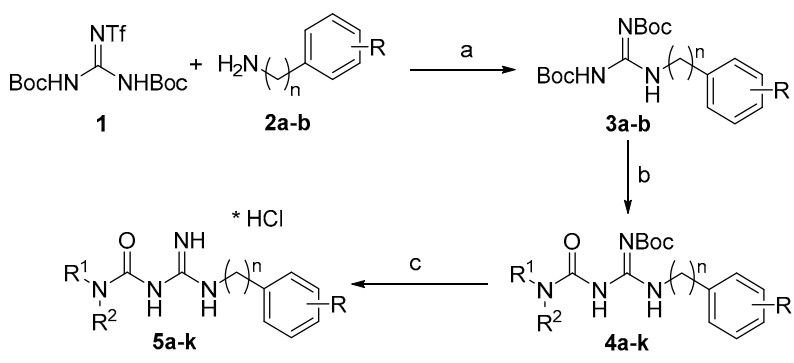

Reaction conditions: a) $\mathrm{Et}_{3} \mathrm{~N}, \mathrm{DCM}$, rt to reflux, 24-48h;

b) amine, $\mathrm{Et}_{3} \mathrm{~N}$, THF, reflux, $24-48 \mathrm{~h}$; c) $\mathrm{HCl} / \mathrm{AcOEt}$

Scheme 1. Synthesis of amidinourea derivatives $5 \mathbf{a}-\mathbf{k}$.

Benzyl amine and p-Cl-aniline were reacted with 1,3-di-Boc-2-(trifluoromethylsulfonyl) guanidine $\mathbf{1}$ in DCM and in the presence of $\mathrm{Et}_{3} \mathrm{~N}$ affording the substituted guanidines $\mathbf{3 a}-\mathbf{b}$ in high yields. These latter were then reacted with various primary and secondary amines in refluxing THF to afford the desired Boc-protected amidinoureas $4 \mathbf{a}-\mathbf{k}$ after 24-48 h. The deprotection of $\mathbf{4} \mathbf{a}-\mathbf{k}$ was carried out in $\mathrm{HCl} / \mathrm{AcOEt}$ leading to desired amidinoureas $\mathbf{5 a - k}$ as hydrochloride salts in high yields (Figure 2). Full details regarding preparation procedures and characterization data are included in the Supplementary Materials. 


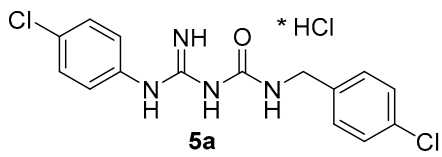<smiles>CC(NC(=O)NC(=N)Nc1ccc(Cl)cc1)c1ccccc1</smiles><smiles>Cc1ccc(CNC(=O)NC(=N)Nc2ccc(Cl)cc2)cc1</smiles><smiles>N=C(NC(=O)N1CCOCC1)Nc1ccc(Cl)cc1</smiles><smiles>N=C(NC(=O)NCCNc1ccccc1)Nc1ccc(Cl)cc1</smiles><smiles>N=C(NC(=O)N1CCNC(c2ccccc2)C1)Nc1ccc(Cl)cc1</smiles><smiles>N=C(NCc1ccccc1)NC(=O)N1CCN(c2ccccc2)CC1</smiles><smiles>N=C(NCc1ccccc1)NC(=O)N1CCN(c2ccc(F)cc2)CC1</smiles><smiles>N=C(NC(=O)N1CCN(c2ccccc2)CC1)Nc1ccc(Cl)cc1</smiles><smiles>N=C(NCc1ccccc1)NC(=O)N1CCN(c2ccc(Cl)cc2)CC1</smiles><smiles>N=C(NC(=O)N1CCN(C23CC4CC(CC(C4)C2)C3)CC1)Nc1ccc(Cl)cc1</smiles>

Figure 2. Structures of the amidinourea derivatives $\mathbf{5 a - k}$.

We then investigated whether the new amidinourea derivatives $\mathbf{5 a}-\mathbf{k}$ could affect HSV-1 and HSV-2 replication. We first assessed cell cytotoxicity of the compounds in African green monkey kidney cells (Vero) to rule out the possibility that antiviral activity was related to the cytotoxic effects of the drug (Table 1). Vero cells were seeded at a density of $3 \times 10^{4} /$ well in a 96-well culture plate. After $24 \mathrm{~h}$, the cells were treated with different dilutions of drugs, or mock-treated using the same amount of vehicle solution (DMSO). Forty-eight hours after treatment, cell viability was determined using a standard 3-(4,5dimethylthiazol-2-yl)-2,5-diphenyltetrazolium bromide (MTT) assay. The 50\% cytotoxic concentration $\left(\mathrm{CC}_{50}\right)$ values are reported in Table 1 . The compounds were considered non-toxic only if they maintained at least $70 \%$ cell viability after $48 \mathrm{~h}$ of treatment.

Table 1. Cytotoxicity of the amidinourea derivatives $\mathbf{5 a - k}$.

\begin{tabular}{cc}
\hline Compound & CC $_{\mathbf{5 0}}{ }^{\mathbf{1}}$ Values $(\boldsymbol{\mu M})$ \\
\hline $\mathbf{5 a}$ & 168.498 \\
$\mathbf{5 b}$ & 196.402 \\
$\mathbf{5 c}$ & 184.303 \\
$\mathbf{5 d}$ & 1557.984 \\
$\mathbf{5 e}$ & 142.274 \\
$\mathbf{5 f}$ & 98.575 \\
$\mathbf{5 g}$ & 245.538 \\
$\mathbf{5 h}$ & 388.580 \\
$\mathbf{5 i}$ & 149.218 \\
$\mathbf{5 j}$ & 176.528 \\
$\mathbf{5 k}$ & 86.733 \\
\hline
\end{tabular}

${ }^{1} \mathrm{CC}_{50}$, compound concentration that produces $50 \%$ of cytotoxicity, as determined by MTT assays in Vero cells. 
Amidinourea 5a-k derivatives were then evaluated for their antiviral activity against HSV-1 and HSV-2 at the minimum effective dose that did not show particular cytotoxicity (100 $\mu \mathrm{M}$ for $\mathbf{5 a}-\mathbf{e}$ and $\mathbf{5 g}-\mathbf{j} ; 50 \mu \mathrm{M}$ for $\mathbf{5 f}$ and $\mathbf{5 k}$, based on MTT results). Data are reported in Figure 3. Vero cells were seeded at a density of $3 \times 10^{5} /$ well in a 24 -well culture plate. Twenty-four hours later, the cells were pre-treated with the different drugs for $2 \mathrm{~h}$ at $37^{\circ} \mathrm{C}$, and then infected in duplicate with HSV-1 or HSV-2 at an MOI of 0.1 , in the presence of the compounds; following virus adsorption, the viral inoculum was removed and cultures were exposed to the compounds for $48 \mathrm{~h}$. The extent of HSV-1 and HSV-2 replication was then assessed by titrating the infectivity of supernatants and cell-associated viruses using a standard plaque assay in Vero cells. Plaques were microscopically counted, and the mean plaque counts for each drug concentration were expressed as plaque-forming units per milliliter (PFU/mL) (Figure 3). All the compounds inhibited both HSV-1 and HSV-2 replication by over $90 \%$. Interestingly, the compounds $5 \mathbf{i}, 5 \mathbf{j}$ and $5 \mathbf{k}$ showed a very strong activity against both HSV-1 and HSV-2. The antiviral activity of the compound $\mathbf{5 d}$, isostere of moroxydine, is more pronounced against HSV-1, while compounds $\mathbf{5 a -} \mathbf{c}$ and $\mathbf{5 e - \mathbf { f }}$ are more active against HSV-2. It is noteworthy that moroxydine does not show any antiviral activity against both HSV-1 and HSV-2 strains (Figure 3).

A)
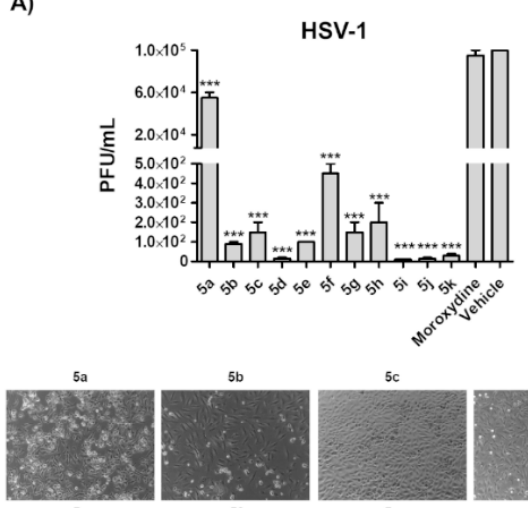

$5 \mathrm{e}$
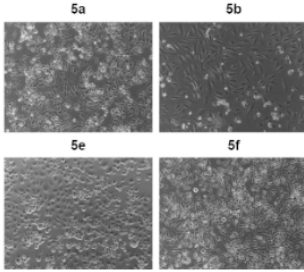

$5 f$
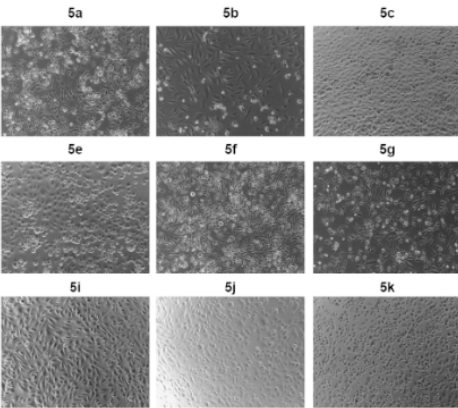

$5 \mathrm{~g}$
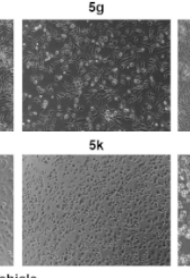
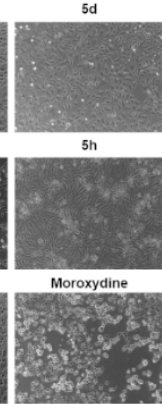

3
$x^{2}$

B)
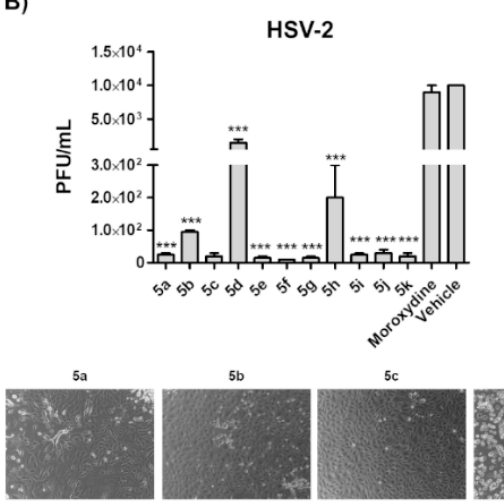

5e
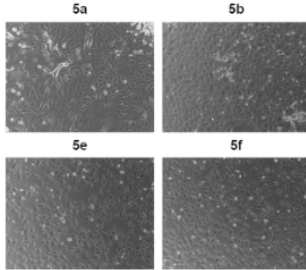

$5 f$

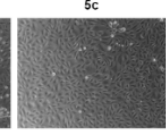

$5 \mathrm{~g}$
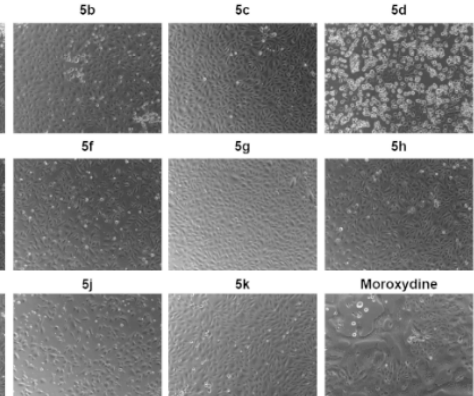

$5 k$

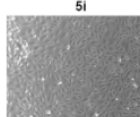

5)
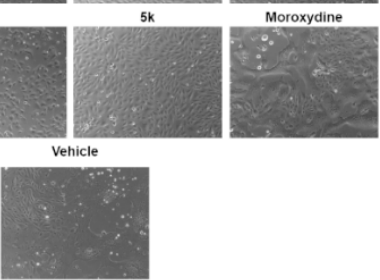

Figure 3. Antiviral activity of $\mathbf{5 a}-\mathbf{k}$ against HSV-1 and HSV-2. Upper panel. Virus yield reduction assay. Vero cells were treated as described in the manuscript with the indicated compounds. The extent of (A) HSV-1 and (B) HSV-2 replication was then assessed by titrating the infectivity of supernatants and cell-associated viruses using a standard plaque assay in Vero cells. Plaques were microscopically counted, and the mean plaque counts for each molecule were expressed as PFU $/ \mathrm{mL}$. Mean \pm SEM is shown ( ${ }^{* * *}, p<0.001$, one-way ANOVA followed by Bonferroni's post-tests). Lower panel. Representative light microscopy images of Vero cells infected with (A) HSV-1 or (B) HSV-2 and treated with the indicated compounds, as described for virus yield reduction assay. Original magnification: $20 \times$.

For the more promising compounds $\mathbf{5 i}, \mathbf{5} \mathbf{j}$ and $\mathbf{5 k}$, a more detailed analysis with serial dilutions of the compounds revealed that they specifically inhibited HSV-1 replication in a dose-dependent manner (Figure $4 \mathrm{~A}$ ), with the half maximal inhibitory concentration $\left(\mathrm{IC}_{50}\right)$ values of 25.26, 72.08 and $18.52 \mu \mathrm{M}$, respectively (Figure 4B). 
A)

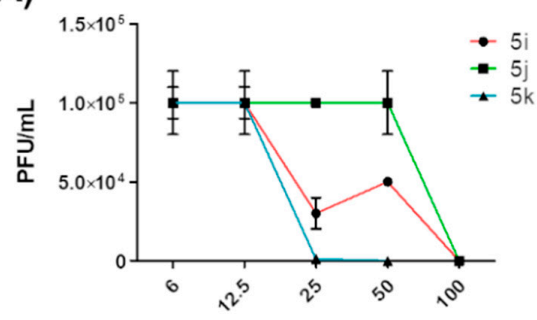

B)

\begin{tabular}{cc}
\hline Compound & $\mathrm{IC}_{50}$ values $(\boldsymbol{\mu M})$ \\
\hline $5 i$ & 25.26 \\
$5 j$ & 72.08 \\
$5 \mathrm{k}$ & 18.52 \\
\hline
\end{tabular}

Figure 4. (A) Vero cells were infected with HSV-1 and, where indicated, the cells were treated with increasing concentrations of the indicated compounds, before and during virus adsorption. These remained in the culture media throughout the experiment. The extent of HSV-1 replication was then assessed by titrating the infectivity of supernatants and cell-associated viruses-obtained from freeze (liquid nitrogen)/ thaw $\left(37^{\circ} \mathrm{C}\right)$ cycles-and combined using a standard plaque assay. Plaques were microscopically counted, and the mean plaque counts for each drug concentration were expressed as $\mathrm{PFU} / \mathrm{mL}$. The number of plaques was plotted as a function of drug concentration. (B) $\mathrm{IC}_{50}$ values, i.e., compound concentration required to inhibit $50 \%$ of viral infectivity.

Finally, to identify the phase of HSV replication program that is affected by amidinourea derivatives, the effects of $5 \mathbf{i}$ compound on viral gene expression was investigated in HSV-1 and HSV-2-infected cells. To this end, the total protein cell extracts were prepared from HSV-infected Vero cells treated with 5i, or vehicle control, for various lengths of time post infection. The expression patterns of ICP27, for HSV-1, ICP8, for HSV-2, gD, for HSV-1 and HSV-2, were then examined via immunoblotting with specific antibodies and were used as a reflection of the levels of immediate-early/early (ICP27, ICP8) and late $(\mathrm{gD})$ viral products, respectively. As shown in Figure 5, an overall decrease of viral proteins was observed at every time point. These results indicate that $5 \mathbf{i}$ interferes with a molecular event that occurs in an early stage of the HSV replication cycle, following the viral attachment and entry phases. However, the precise mechanism exploited by amidinourea derivatives to carry out their antiviral activity against HSV still deserves to be elucidated and is beyond the goals of the present communication.

A)

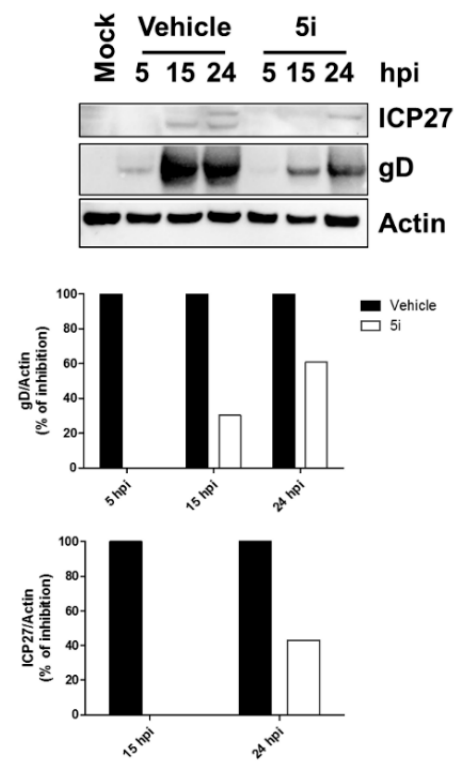

B)

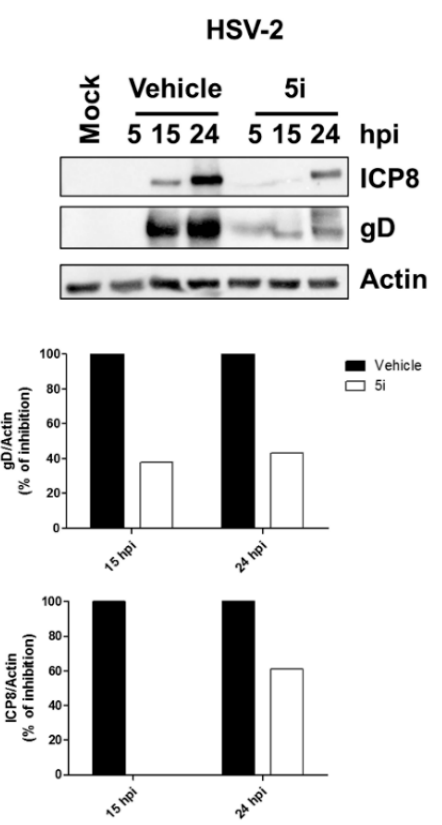

Figure 5. Vero cells were mock infected or infected with HSV-1 (A) or HSV-2 (B) at an MOI of 0.3. Protein levels of ICP27 (HSV-1), ICP8 (HSV-2) and gD (HSV-1/2) were assessed at different times post infection (hpi) by Western blotting (upper panels). Viral proteins were subjected to densitometry and normalized to Actin, serving as a loading control (lower panels). 


\section{Materials and Methods}

\subsection{Chemistry-General Methods}

NMR spectra were recorded on Bruker Ascend ${ }^{\mathrm{TM}} 400 \mathrm{MHz}$ spectrometer. ${ }^{1} \mathrm{H}$ and ${ }^{13} \mathrm{C}$ spectra were referenced relative to the solvent residual peaks and chemical shifts

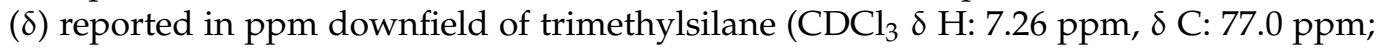
$\mathrm{CD}_{3} \mathrm{OD}-d_{4} \delta \mathrm{H}: 3.31 \mathrm{ppm}, \delta \mathrm{C}: 49.05$ ppm; DMSO- $\left.d_{6} \delta \mathrm{H}: 2.50 \mathrm{ppm}, \delta \mathrm{C}: 39.52 \mathrm{ppm}\right)$. Coupling constants (J) are reported in Hertz and rounded to $0.5 \mathrm{~Hz}$. Splitting patterns are abbreviated as follows: singlet $(\mathrm{s})$, doublet $(\mathrm{d})$, triplet $(\mathrm{t})$, quartet $(\mathrm{q})$, multiplet $(\mathrm{m})$, broad (br) or some combination of these. Thin-layer chromatography (TLC) was performed using commercially available precoated plates and visualized with UV light at $254 \mathrm{~nm}$; $\mathrm{KMnO}_{4}$ or ninhydrin dips were used to reveal the products. Flash column chromatography were carried out using Aldrich Chemistry 40-63 $\mu \mathrm{m} 60 \AA$ A. All solvents and commercially available reagents were used as received. All chemicals and solvents were used as supplied, unless noted otherwise. The amount of compounds obtained as oils was quantified by weight. The isolated clean fraction of the oils resuspended in dichloromethane was dried using rotary evaporation first, and then a high-vacuum pump. Full characterization of compounds $\mathbf{4} \mathbf{- 5}$ is reported in the Supporting Information.

\subsection{Biology}

\subsubsection{Cells and Viruses}

The African green monkey kidney cells (Vero, ATCC CCL- $81^{\mathrm{TM}}$ ) were cultured in Dulbecco's Modified Eagle's Medium, supplemented with 10\% heat inactivated fetal bovine serum (FBS), $2 \mathrm{mM}$ glutamine, $1 \mathrm{mM}$ sodium pyruvate, $100 \mathrm{U} / \mathrm{mL}$ penicillin and $100 \mu \mathrm{g} / \mathrm{mL}$ streptomycin sulfate (Sigma-Aldrich, Milan, Italy). Clinical isolates of HSV-1 and HSV-2 were a generous gift from Valeria Ghisetti, Amedeo di Savoia Hospital, Turin, Italy. They were propagated and titrated by plaque assay on Vero cells, as previously described [26].

\subsubsection{Virus Yield Reduction Assay}

Vero cells were seeded in 24-well plates and pre-treated, after $24 \mathrm{~h}$, with different concentrations of the amidinourea derivatives or the vehicle control (DMSO) for $2 \mathrm{~h}$ at $37^{\circ} \mathrm{C}$. They were then infected with HSV at MOI of $0.1 \mathrm{PFU} /$ cell in the presence of the compounds. Following virus adsorption $\left(2 \mathrm{~h}\right.$ at $\left.37^{\circ} \mathrm{C}\right)$, the viral inoculum was removed, and the cultures were maintained in a medium that contained the corresponding molecule for $48 \mathrm{~h}$. The cells and supernatants were then harvested and disrupted using three freeze (liquid nitrogen)/thaw $\left(37^{\circ} \mathrm{C}\right)$ cycles. The extent of virus replication was subsequently assessed by titrating the infectivity of the supernatants of the cell suspensions in Vero cells, as previously described [26]. Plaques were microscopically counted, and the mean plaque counts for each drug concentration were expressed as PFU/mL.

\subsubsection{Cytotoxicity Assay}

To determine the cytotoxicity of amidinourea derivatives, Vero cells were seeded in a 96-well culture plate and exposed to increasing concentrations of either compounds or vehicle (DMSO) the following day. After $48 \mathrm{~h}$ of incubation, the number of viable cells was determined using the 3-(4,5-dimethylthiazol-2-yl)-2,5-diphenyltetrazolium bromide (MTT) (Sigma-Aldrich, Milan, Italy) assay, as previously described [27].

\subsubsection{Western Blot Analysis}

After treatment, the cells were washed with phosphate-buffered saline (PBS), and cell lysis was carried out using radioimmunoprecipitation assay (RIPA) buffer to obtain total cell lysate. An equal amount of the cell extracts was fractionated by electrophoresis on sodium dodecyl sulfate polyacrylamide gels and transferred to Immobilon-P membranes (Bio-Rad, Milan, Italy). After blocking with $5 \%$ nonfat dry milk in TBS-Tween $0.05 \%$, the membranes were incubated overnight at $4{ }^{\circ} \mathrm{C}$ with the appropriate primary antibodies. 
The following primary antibodies were used: mouse monoclonal antibodies anti-HSV-1 ICP27 monoclonal antibody (MAb) (clone H1113, Virusys Corporation), mouse anti-HSV-2 ICP8 MAb (clone 4E6, Virusys Corporation), mouse anti-HSV-1/2 gD MAb (clone 2C10, Virusys Corporation) and anti-Actin (clone C4, MAB1501) (Sigma-Aldrich, Milan, Italy) (all at 1:1000 dilution in 5\% nonfat dry milk, TBS-Tween 0.05\%). After washing with TBST buffer ( $500 \mathrm{mM} \mathrm{NaCl}, 20 \mathrm{mM}$ Tris $\mathrm{pH} 7.4,0.05 \%$ Tween 20 ), the membrane was incubated with an HRP-conjugated anti-mouse secondary antibody (GE Healthcare, Chicago, IL, USA) for $1 \mathrm{~h}$ at room temperature, and visualized using an enhanced chemiluminescence detection kit (SuperSignal West Pico Chemiluminescent Substrate, Thermo SCIENTIFIC, Waltham, MA, USA). Scanning densitometry of the bands was performed using Images Lab software (Bio-Rad, Hercules, CA, USA).

\subsubsection{Statistical Analysis}

Data were presented as the mean value and standard error of the mean (SEM). Data were analyzed by means of GraphPad Prism 5 software (GraphPad Software, Inc., La Jolla, CA, USA). Statistical analysis was performed using one-way ANOVA with Bonferroni's posttest; $p<0.05$ was considered statistically significant. The $\mathrm{IC}_{50}$ e $\mathrm{CC}_{50}$ values were calculated using the online tool Quest Graph ${ }^{\mathrm{TM}} \mathrm{IC}_{50}$ Calculator, AAT Bioquest, Inc., Sunnyvale, CA, USA, https:/ / www.aatbio.com/tools/ic50-calculator (accessed on 4 May 2021).

\section{Conclusions}

In conclusion, a series of amidinourea compounds has be designed using the moroxydine scaffold as a template. The new compounds have been evaluated for their activity against HSV-1 and HSV-2 showing a good antiviral activity at micromolar concentrations in the case of derivatives $\mathbf{5 i}, \mathbf{5} \mathbf{j}$ and $\mathbf{5 k}$. These three most active amidinoureas also showed low cytotoxicity in Vero cells, resulting in promising hit compounds for following structure optimization studies. Early studies to elucidate the mode of action have been carried out. Being non-nucleoside inhibitors of HSV-1, it is likely that the new amidinourea compounds may act with an antiviral mechanism different from that of classic anti-HSV drugs such as acyclovir. Preliminary studies indicate that $5 \mathrm{i}$ inhibits HSV at the early stage of replication, in line with previous observations on the antiviral activity of amidinourea compounds on other viruses [25].

Supplementary Materials: The following are available online: full characterization of compounds 4-5 ( ${ }^{1} \mathrm{H}-\mathrm{NMR}$ and $\left.{ }^{13} \mathrm{C}-\mathrm{NMR}, \mathrm{MS}\right)$.

Author Contributions: Conceptualization, D.C. and V.D.; methodology, A.T., S.A., S.F.C.P. and M.B.; validation, A.T., R.D. and S.A.; formal analysis, R.D., A.T. and M.B.; investigation, R.D. and A.T.; writing - review and editing, D.C., V.D. and M.B.; supervision, D.C., V.D., A.T. and M.B.; project administration, D.C. and V.D.; funding acquisition, D.C., V.D., A.T. and M.B. All authors have read and agreed to the published version of the manuscript.

Funding: This research was funded by the University of London (CW Maplethorpe Fellowship), the Italian Ministry of Education, the University and Research-MIUR (PRIN 20178ALPCM), "Cassa di Risparmio" Foundation of Turin ( $R F=2019.2273)$ and the University of Turin (RILO 2020).

Institutional Review Board Statement: Not applicable.

Informed Consent Statement: Not applicable.

Data Availability Statement: Not applicable.

Acknowledgments: University of London is acknowledged for the CW Maplethorpe Fellowship to A.T. This research was supported by the Italian Ministry of Education, University and Research-MIUR (PRIN 20178ALPCM) (V.D.), “Cassa di Risparmio" Foundation of Turin (RF = 2019.2273) (V.D.), and the University of Turin (RILO 2020) (V.D. and M.B).

Conflicts of Interest: The authors declared no conflict of interest.

Sample Availability: Samples of the compounds are available from the authors. 


\section{References}

1. Pinna, D.; Oreste, P.; Coradin, T.; Kajaste-Rudnitski, A.; Ghezzi, S.; Zoppetti, G.; Rotola, A.; Argnani, R.; Poli, G.; Manservigi, R.; et al. Inhibition of herpes simplex virus types 1 and 2 in vitro infection by sulfated derivatives of Escherichia coli K5 polysaccharide. Antimicrob. Agents Chemother. 2008, 52, 3078-3084. [CrossRef]

2. Whitley, R.J.; Roizman, B. Herpes simplex virus infections. Lancet 2001, 357, 1513-1518. [CrossRef]

3. Eisenstein, L.E.; Calio, A.J.; Cunha, B.A. Herpes simplex (HSV-1) aseptic meningitis. Heart Lung 2004, 33, 196-197. [CrossRef] [PubMed]

4. Szczubiałka, K.; Pyrć, K.; Nowakowska, M. In search for effective and definitive treatment of herpes simplex virus type 1 (HSV-1) infections. RSC Adv. 2016, 6, 1058-1075. [CrossRef]

5. Smith, J.S.; Robinson, N.J. Age-Specific Prevalence of Infection with Herpes Simplex Virus Types 2 and 1: A Global Review. J. Infect. Dis. 2002, 186, S3-S28. [CrossRef] [PubMed]

6. Roizman, B.; Whitley, R.J. An inquiry into the molecular basis of HSV latency and reactivation. Annu. Rev. Microbiol. 2013, 67, 355-374. [CrossRef] [PubMed]

7. Available online: https://www.who.int/bulletin/volumes/98/5/19-237149/en/ (accessed on 10 June 2021).

8. Gupta, R.; Warren, T.; Wald, A. Genital herpes. Lancet 2007, 370, 2127-2137. [CrossRef]

9. Looker, K.J.; Garnett, G.P. A systematic review of the epidemiology and interaction of herpes simplex virus types 1 and 2. Sex. Transm. Infect. 2005, 81, 103-107. [CrossRef] [PubMed]

10. Itzhaki, R.F.; Lin, W.R.; Shang, D.; Wilcock, G.K.; Faragher, B.; Jamieson, G.A. Herpes simplex virus type 1 in brain and risk of Alzheimer's disease. Lancet 1997, 349, 241. [CrossRef]

11. Letenneur, L.; Pérès, K.; Fleury, H.; Garrigue, I.; Barberger-Gateau, P.; Helmer, C.; Orgogozo, J.M.; Gauthier, S.; Dartigues, J.F. Seropositivity to herpes simplex virus antibodies and risk of Alzheimer's disease: A population-based cohort study. PLoS ONE 2008, 3, e3637. [CrossRef]

12. Wozniak, M.A.; Frost, A.L.; Preston, C.M.; Itzhaki, R.F. Antivirals reduce the formation of key Alzheimer's disease molecules in cell cultures acutely infected with herpes simplex virus type 1. PLoS ONE 2011, 6, e25152. [CrossRef] [PubMed]

13. Kłysik, K.; Pietraszek, A.; Karewicz, A.; Nowakowska, M. Acyclovir in the treatment of herpes viruses-A review. Curr. Med. Chem. 2020, 27, 4118-4137. [CrossRef] [PubMed]

14. Hammer, K.D.P.; Dietz, J.; Lo, T.S.; Johnson, E.M. A systematic review on the efficacy of topical acyclovir, penciclovir, and docosanol for the treatment of herpes simplex labialis. EMJ Dermatol. 2018, 6, 118-123.

15. Khan, M.T.H.; Ather, A.; Thompson, K.D.; Gambari, R. Extracts and molecules from medicinal plants against herpes simplex viruses. Antivir. Res. 2005, 67, 107-119. [CrossRef] [PubMed]

16. Andrei, G.; Snoeck, R. Herpes simplex virus drug-resistance: New mutations and insights. Curr. Opin. Infect. Dis. 2013, 26, 551-560. [CrossRef]

17. Clercq, E.D.; Li, G. Approved antiviral drugs over the past 50 years. Clin. Microbiol. Rev. 2016, 29, 695-747. [CrossRef]

18. Castagnolo, D. Chemistry and biological properties of amidinoureas: Strategies for the synthesis of unique bioactive hit compounds. In New Strategies in Chemical Synthesis and Catalysis; Pignataro, B., Ed.; Wiley-VCH: Weinheim, Germany, 2012; Chapter 5 .

19. Castagnolo, D.; Raffi, F.; Giorgi, G.; Botta, M. Macrocyclization of di-Boc-guanidino-alkylamines related to guazatine components: Discovery and synthesis of innovative macrocyclic amidinoureas. Eur. J. Org. Chem. 2009, 2009, 334-337. [CrossRef]

20. Manetti, F.; Castagnolo, D.; Raffi, F.; Zizzari, A.T.; Rajamäki, S.; D’Arezzo, S.; Visca, P.; Cona, A.; Fracasso, M.E.; Doria, D.; et al. Synthesis of new linear guanidines and macrocyclic amidinourea derivatives endowed with high antifungal activity against Candida spp. and Aspergillus spp. J. Med. Chem. 2009, 52, 7376-7379. [CrossRef] [PubMed]

21. Sanguinetti, M.; Sanfilippo, S.; Castagnolo, D.; Sanglard, D.; Posteraro, B.; Donzellini, G.; Botta, M. Novel macrocyclic amidinoureas: Potent non-azole antifungals active against wild-type and resistant Candida species. ACS Med. Chem. Lett. 2013, 4, 852-857. [CrossRef] [PubMed]

22. Bass, R.; Jenkinson, S.; Wright, J.; Smulders-Srinivasan, T.; Marshall, J.C.; Castagnolo, D. Synthesis and biological evaluation of amidinourea and triazine congeners as inhibitors of MDA-MB-231 human breast cancer cell proliferation. ChemMedChem 2017, 12, 288-291. [CrossRef] [PubMed]

23. Orofino, F.; Truglio, G.I.; Fiorucci, D.; D’Agostino, I.; Borgini, M.; Poggialini, F.; Zamperini, C.; Dreassi, E.; Maccari, L.; Torelli, R.; et al. In vitro characterization, ADME analysis, and histological and toxicological evaluation of BM1, a macrocyclic amidinourea active against azole-resistant Candida strains. Int. J. Antimicrob. Agents 2020, 55, 105865. [CrossRef]

24. Magri, A.; Mokrane, O.; Lauder, K.; Patel, A.H.; Castagnolo, D. Rethinking the old antiviral drug moroxydine: Discovery of novel analogues as anti-hepatitis C virus (HCV) agents. Bioorg. Med. Chem. Lett. 2019, 29, 724-728. [CrossRef] [PubMed]

25. Magri, A.; Reilly, R.; Scalacci, N.; Radi, M.; Hunter, M.; Ripoll, M.; Patel, A.; Castagnolo, D. Synthesis, Biological Evaluation and Mode of Action Studies of Novel Amidinourea Inhibitors of Hepatitis C Virus (HCV). Bioorg. Med. Chem. Lett. 2015, 25, 5372-5376. [CrossRef] [PubMed]

26. Biolatti, M.; Blangetti, M.; D’Arrigo, G.; Spyrakis, F.; Cappello, P.; Albano, C.; Ravanini, P.; Landolfo, S.; De Andrea, M.; Prandi, C.; et al. Strigolactone analogs are promising antiviral agents for the treatment of human cytomegalovirus infection. Microorganisms 2020, 8, 703. [CrossRef] [PubMed]

27. Tumer, T.B.; Yılmaz, B.; Ozleyen, A.; Kurt, B.; Taskın, T.T.; Taskin, K.M.; Kulabas, S.S. GR24, a synthetic analog of Strigolactones, alleviates inflammation and promotes Nrf2 cytoprotective response: In vitro and in silico evidences. Comput. Biol. Chem. 2018, 76, 179-190. [CrossRef] [PubMed] 